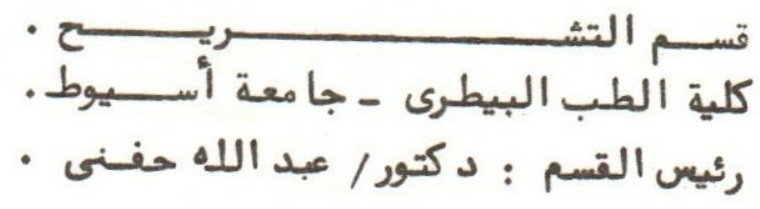

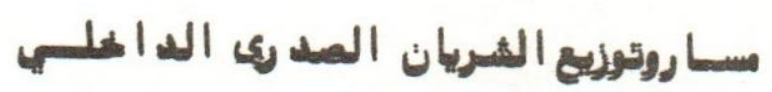

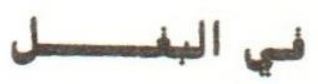

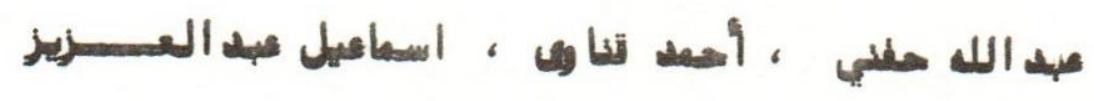

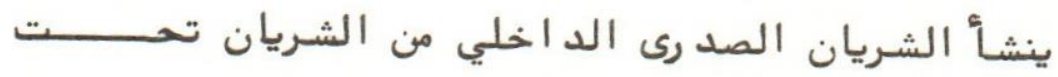

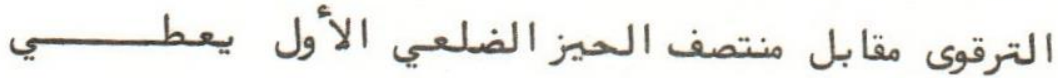

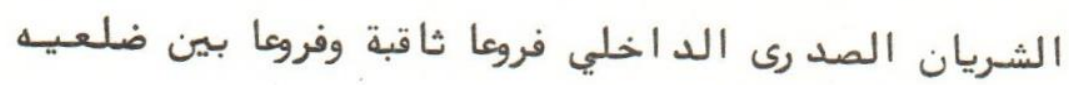

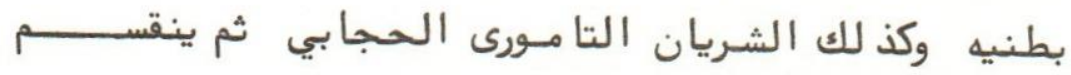

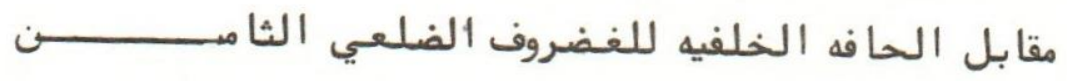
أو السادس الى الشـريان العضلي الحجابي والشرسـوفسي

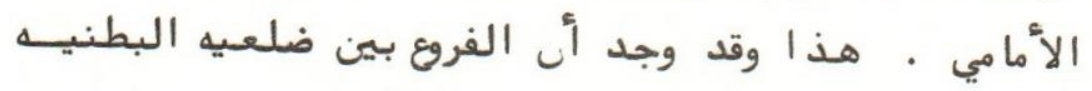
التي تخرج من الشـريان الصد رى الداخلي تتحسد د مسـع

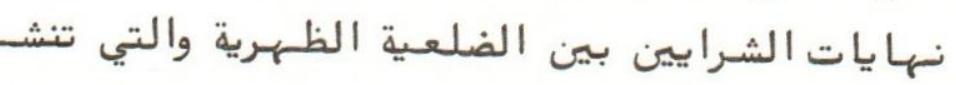
مسن الأبهـر الصــد رى . 
Dept. of Anatomy and Histology, Faculty of Vet. Med., Assiut University, Head of Dept. Dr. A. Hifny.

\title{
COURSE AND DISTRIDBUTION OF A. THORACICA INTERNA IN MULE (Equus hinnus) (With One Fig.)
}

\author{
By \\ A. HIFNY, A.K. AHMED and I.A. IBRAHIM \\ (Received at 16/11/1981)
}

\begin{abstract}
SUMMARY
The origin, course and distribution of the internal thoracic artery in mule (Equus hinnus) were completely described.

The brawnches and termination of the internal thoracic artery in mule resemble those found in most domestic animals, however, the differences between this animal and other domestic animals were discussed.
\end{abstract}

\section{INTRODUCTION}

The available literature about the anatomy of the vascular system of the mule is meagre. The aim of this study is to describe the arterial blood supply of the ventral wall of the thorax. The obtained results were completly discussed with that of other domestic animals.

\section{MATERIAL and METHODS}

This study was carried out on 10 adult healthy mules, 7 males and females. The animals were bled, injected through the common carotid artery with 10\% formalin solution, then with gum milk (Latex) after about one week. The Nomenclature used is that adopted by NOMINA ANATOMICA VETERINARIA (1973).

\section{RESULTS}

The internal thoracic artery $(1 / 1)$ is given off the ventral aspect of the subclavian artery at the level of the 1st intercostal space. It courses gently in a ventrocaudal direction under the pariatal pleura. At the level of the 2 nd rib, it continues its course caudally under cover of M. transversus thoracic to terminate at a level with the caudal border of the eight costal cartilage by dividing into A. musculophrnica and A. epigastrica cranialis.

Along its course, the internal thoracic artery detaches Rr. intercostales ventrales II-V, Rr. perforantes $I-$ VII and A. perciordiacophrenica, in addition to Rr. sternales.

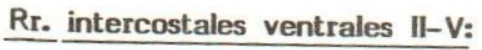

Each ventral intercostal branch $(1 / 2)$ arises at the corresponding interchondral space, and ascends between $\mathrm{Mm}$. intercostales interni and transversus thoracis. On reaching the level of the costochondral junction, it divides into R. precostalis and R. postcostalis. 


\section{A. HIFNY et al.}

The precostal branch $(1 / 3)$ ascends along the cranial border of the following rib and unites with one of the collateral branches of the dorsal intercostal arteries. It detaches small twigs to $\mathrm{Mm}$. intercostales, serratus ventralis thoracis, pleura and ribs.

The postcostal branch (1/4) which is larger than the precostal one, ascends subpleurally along thevaudal border of the corresponding rib to join the corresponding dorsal intercostal artery. It sends fine twigs to supply $\mathrm{Mm}$. intercostales, rectus thoracis and serratus ventralis thoracis, pleura, and ribs.

\section{Rr. perforantes I-VII:}

The segmental perforating branches $(1 / 5)$ are given of at the level of the corresponding interchondral space. These branches vascularize $M$. transversus thoracis and emerge through the corresponding interchordral spaces to supply the pectoral muscles, cranial part of $M$. rectus abdominis, sternum and skin of the sternal region.

\section{A. pericardiacophrenica:}

The pericardiacophrenic artery $(1 / 6)$ is a very small vessel which arises opposite to the 6th intercostal space.It ascends in the caudal mediastinum on the left side, and in the plica venae cavae on the right side accompanying the corresponding phrenic nerve to supply the diaphragm. Moreover, it gives collateral branches to the pericardium and pleura.

\section{A. musculophranica:}

The musculophrenic artery $(1 / 7)$ is one of the two termoinal branches of the internal thoracic artery and arises at a level with the caudal border of the eighth costal cartilage. It courses in a caudodorsal direction along the costal part of the diaphragm where it terminates by forming an arch with the cranial branch of A. intercostales dorsales XIII.

During its course, the musculophrenic artery detaches Rr. intercostales ventrales VI-XII, Rr. phrenicae and Rr. musculares for M. transversus abdominis.

\section{Rr. intercostales ventrales VI-XIl:}

These ventral intercostal branches $(1 / 8)$ arise segmentally from the musculophrenic artery, at the corresponding interchondral spaces. They ascend between the intercostal muscles, then subpleurally along the caudal border of the corresponding rib to join the dorsal intercostal arteries. They supply the intercostal muscles and pleura. In addition, they give off Rr. cutanei laterales VII-XII which pierce the external oblique abdominal muscle and terminate in $M$. cutaneous trunci, the fascia and skin of the lateral thoracic wall.

\section{Rr. phrenicae:}

Four to six phrenic branches $(1 / 9)$ are given from the dorsal aspect of the musculophrenic artery at irregular intervals. These branches pass dorsally in the costal part of the diaphragm and terminate before reaching its tendinous center.

\section{A. epigastrica cranialis:}

The cranial epigastric rtery $(1 / 10)$ forms the direct continuation of the parent vessel at the level of the caudal border of the 8 th costal cartilage. It passes caudalwards between 


\section{A. THORACICA INTERNA IN MULE}

the 9th costal cartilage and xiphoid process to gain the dorsal aspect of M. rectus abdominis. It continues within the substance of this muscle and terminates by anastomosing with $A$. epigastrica caudalis at the umblical region. It detaches regular segmental Rr. mediales and laterales for M. transversus abdominis.

\section{DISCUSSION}

The origin and mode of division of A. thoracica interna in Equus hinnus resembles that reported by WILKENS and MUNSTER (1976) and SIMOENS et al. (1979) in horse, dog, pig and cattle and in camel by ATTIA (1980).

The division of the ventral intercostal brancvhes into a pre-and postocstal branches was also described by OPTIZ (1961)from the 3rd to the 8th intercostal space in cat,by MORTH EN (1939) and MILLER et al. (1964) from the 2 nd to the 8 th intercostal spaces in dog and by OTTO (1961) from the 2 nd to the 6th intercostal spacve in goat and ATTIA (1980) from the 2nd to the 6th intercostal spaces in camel.

The origin of the pericardiacophrenic artery is similar to that stated by WILKENS and MUNSTER (1976) and SIMOENS et al.(1979) in most domestic animals, while icamel the pericardiacophrenic artery arises by a stem vessel with the superficiai cranial epigastric artery as stated by ATTIA (1980).

The musculophrenic artery in Equus hinnus possesses a similar origin to that of horse as stated by BRADLEY (1949), GHOSHAL (1975) and WILKENS and MUNSTER (1976); in cat by OPTIZ (1961) and CROUCH (1969); in dog by MARTHEN (1939), BRADLEY and GRAHAM (1959) and MILLER et al. (1964) and in cattle by RAGHAVAN (1964).

The ventral intercostal branches of the musculophrenic artery are similar to those in horse (BRADLEY, 1947); in cat (OPTIW, 1961 and CROUCH, 1969); in dog (MARTHEM, 1939); in pig (KAHLER, 1960 and GHOSHAL, 1975) and in cattle (SEIDLER, 1966).

According to WILKENS and MUNSTER (1976) the segmental medial and lateral branches of the cranial epigastric arteryin pig and ruminants anastomose with branches from A. musculophrenica. These anastomoses are not found in Equus hinnus.

\section{RERERENCES}

Attia, M.M. (1980): Anatomical studies on the arterial blood supply of the trunk in the one humped camel (Camelus dromedarius). Thesis M.V.Sc., Assiut Univ.

Bradley, O. (1974): The Topographical Antatomy of the thorax and abdomen of the horse. W. Green and Son, Limited, Edinburgh.

Bradley, O. and Graham (1959): Topographical Anatomy of the dog Edinburgh and London, Oliver and Body.

Crouch, J.E. (1969): Text-Atlas of cat Anatomy. Lea and Febiger, philadelphia.

Ghoshal, N.G. (1975): Heat and arteries in SISSON and GROSSMAN. The Anatomy of the Kahler, w. (1960): Animals. Rev, by R. GETTY; 5th Edition, Ed. I, II. Diss. Med. Vet. 


\section{A. HIFNY, et al.}

Marthen, G. (1939): Uber die Arterien der Koperwand des Hundes. Hannover. Tierarwtl' Hochsch. Diss. Med. Vet.

Miller, M.E., G.G. Christensen and H. Evans (1964): Anatomy of the dog. W.B. Saunders Comp. Philadelphia - London.

Optiw, M. (1961): Arterien der Korperwand der Katze. Hannover, Tierarzt HOCHSCH. Diss. Med. Vet.

Otto E. (1961): Arterien der dorperwand der Ziege. Hannover, Tierarzt. Hochsch' Diss. Med. Vet.

Raghavan, D. (1964): Anatomy of Ox. Indian Concil of Agricultural Research. New Delhi.

Seidler, D. (1966): Arterien und Venen der korperwand des Rindes. Hannover, Tierarzt. Hochsch' Diss. Med. Vet.

Simoens, P., H.R. DE Vos and H. Lauwers (1979): Illustraled Anatomical Nomenclature of the heart and the arteries of the head and neck in the domestic Mammals. Commication of Faculty of Veterinary Medicine, State University Ghent, 1-2, 1-100.

Wilkens, H. and W. Munster (1976): Arterien und venen; In R. NICKEL, A. SCHUMMER und E. SEIFERLE, Lehrbuch der Anatomie der Haustiere B. III. Verlag P. Paprey, BerlinHabuurg.

\section{LEGENDS}

Fig. (1): Diagram showing the course and distribution of A. thoracica interna in mule. (Left side).
A. first rib,
B. sternum,
C. humerus,
D. ulna,

1. A. thoracica interna,

2. Rr. intercostales ventrales,

3. R. precostalis,

4. R. postcostalis,

5. Rr. perforantes,

6. A. pericardiacophrenica,

7. Rr. musculophrenica,

8. Rr. phrenicae,

9. Rr. phrenicae,

10. A. epigastrica cranialis. 


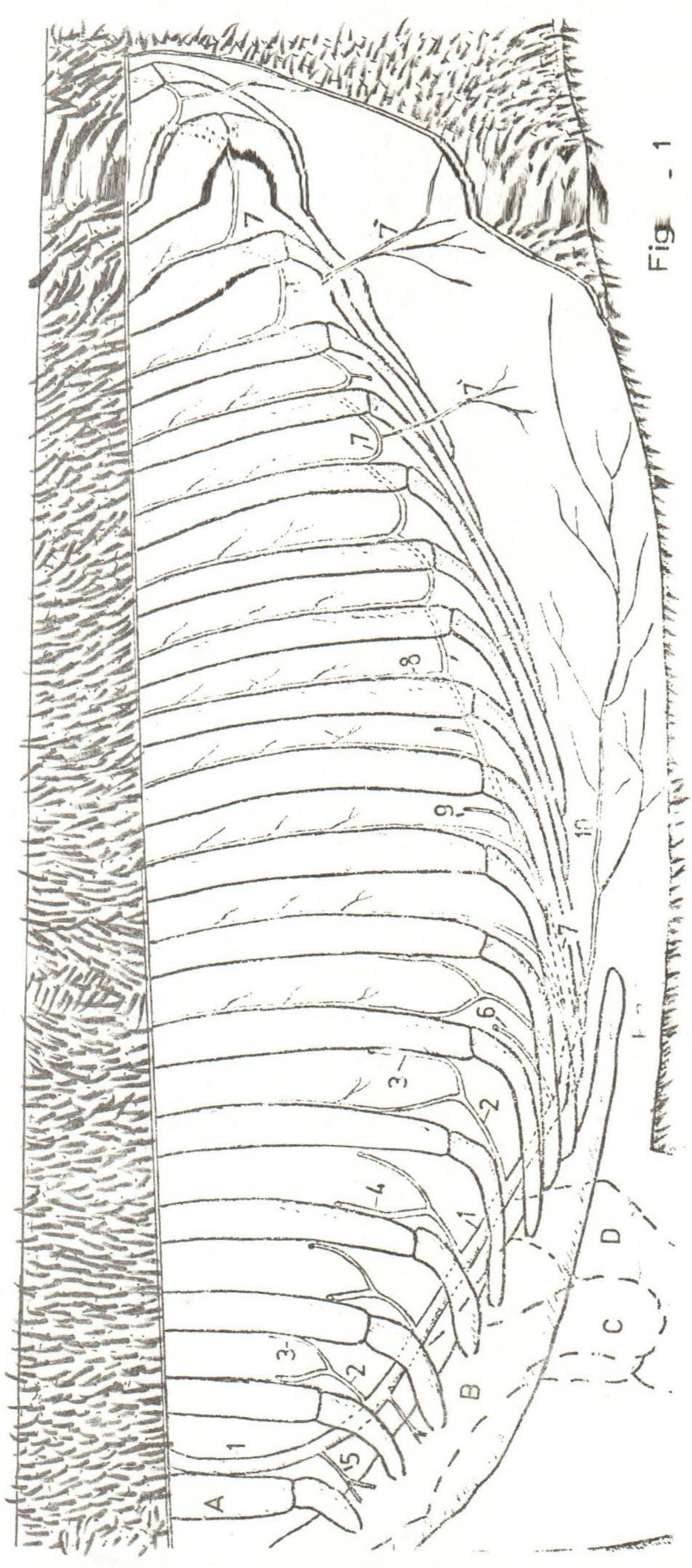

